\title{
Epibiotic bacterial community of Sphaeroma serratum (Crustacea, Isopoda): relationship with molt status
}

\author{
Audrey Caro ${ }^{1, *}$, Arthur Escalas ${ }^{1}$, Corinne Bouvier ${ }^{1}$, Evelyse Grousset ${ }^{1}$, \\ Nicole Lautredou-Audouy ${ }^{2}$, Cécile Roques ${ }^{1}$, Mireille Charmantier ${ }^{1}$, Olivier Gros ${ }^{3}$ \\ ${ }^{1}$ UMR-CNRS 5119, Laboratoire Ecologie des Systèmes Marins Côtiers, Université Montpellier II, 34095 Montpellier, \\ Cedex 5, France \\ ${ }^{2}$ INSERM U554, CNRS UMR 5048, Montpellier, France \\ ${ }^{3}$ UMR-CNRS 7138, Systématique-Adaptation-Evolution, Equipe 'Biologie de la mangrove', BP 592, \\ Université des Antilles et de la Guyane, 97159 Pointe-à-Pitre Cedex, Guadeloupe, France
}

\begin{abstract}
Sphaeroma serratum is a marine isopod species that inhabits seashores from Europe to West Africa. The individuals live under stones in direct contact with reduced sediments and harbour a diverse bacterial community on the cuticle of their pleopods. We investigated the diversity of these epibiotic bacteria on male (pubescent and senescent) and female specimens with electron microscopic observations and molecular tools. The microbial community of $S$. serratum was shown to be composed of at least 5 bacterial morphotypes observed on the pleopodal cuticle in all male specimens. Using fluorescence in situ hybridization, we identified 5 major phylogenetic groups $(\alpha-, \beta-, \gamma$ - and $\delta$-Proteobacteria and Archaea) whereas denaturing gradient gel electrophoresis (DGGE) of PCR-amplified 16S rRNA gene fragments of epibiotic bacteria revealed 50 bands. The bacterial community associated with $S$. serratum seems more diverse than in other marine crustaceans, such as Rimicaris. The relative diversity of this bacterial community was also studied in relation to the molt cycle. The comparison of DGGE band patterns of several individuals from female, pubescent male and senescent male groups revealed that the bacterial community diversity was dependent on the sex and the age of the individuals and more generally on the molt status.
\end{abstract}

KEY WORDS: Sphaeroma - Molt cycle - Epibiotic biofilm - DGGE band pattern - FISH · Crustacean

Resale or republication not permitted without written consent of the publisher

\section{INTRODUCTION}

Epibiotic bacteria have been discovered in several groups of invertebrates living mainly in sulphide-rich environments. These symbioses were first described in the shrimp Rimicaris exoculata, a decapod crustacean dominant in the hydrothermal vent community along the Mid-Atlantic ridge (Williams \& Rona 1986). The branchial chamber of $R$. exoculata and its mouthparts harbour a rich epibiotic microbial community (Van Dover et al. 1988, Segonzac et al. 1993, Zbinden et al. 2004). The bacterial community of $R$. exoculata comprises different bacterial morphotypes, affiliated with 2 major phylogenetic groups ( $\gamma$ - and $\varepsilon$-Proteobacteria) and corresponding to 3 metabolic types, including iron sulphide and methane oxidation (Segonzac et al. 1993, Polz \& Cavanaugh 1995, Zbinden et al. 2004, 2008, Petersen et al. 2010). The role of this ectosymbiotic community still remains unclear. It has been suggested that the bacteria harboured in the branchial chamber represent the main source of dietary carbon for the shrimp via digestion of the bacteria (Gebruk et 
al. 1993, Rieley et al. 1999). Other authors (Zbinden et al. 2004) suggested that the epibiotic bacteria on the branchiostegites benefit from a favourable chemical environment downstream of the gills, without any clear advantage for the host (Zbinden et al. 2004). Most studies on epibiotic associations raise the question of whether the epibionts are used as food by the host. There has been no clear answer so far.

Besides Rimicaris exoculata, other invertebrate groups living near hydrothermal vents are known to harbour an epibiotic bacterial community, such as polychaete annelids (Alvinella) (Desbruyères et al. 1998, Dubilier et al. 2008) a aplacophoran molluscs (Helicoradomenia spp.) (Katz et al. 2006). Moreover, some studies have revealed the presence of epibiotic bacteria in association with invertebrates living at shallow depth in the seashore environment, as described for molluscs (Gillan \& De Ridder 1997, Gillan et al. 1998, 2004), ascidians (Tait et al. 2007) or echinoderms (Brigmon \& De Ridder 1998). For Crustacea, a small amphipod, Urothoe posedonis, living in marine sediment or as a commensal in the burrows of various invertebrates (Gillan et al. 2004, Lackschewitz \& Reise 1998) was described to be associated with an iron-encrusted epibiotic microbial community (Gillan et al. 2004). Filamentous bacteria were dominant in the community of this amphipod and 1 of the 3 filamentous morphotypes was identified by denaturing gradient gel electrophoresis (DGGE) and phylogenetic analysis as Thiotrix, belonging to the $\gamma$ Proteobacteria (Gillan \& Dubilier 2004). Although most of the epibiotic communities with invertebrates have been described for marine environments, there is a single report of chemoautotrophic bacteria (Thiotrix) associated with the freshwater cave amphipod Niphargus ictus (Dattagupta et al. 2009).

Isopoda have been rarely investigated in this aspect. A single study has been conducted on the species Sphaeroma serratum (El-Shanshoury et al. 1994), but as it was based on a culture-dependent method, the data on this species remain limited. S. serratum is common with a wide distribution from the European coast (Ireland, Germany) to West Africa (Daguerre de Hureaux 1966). On the French Mediterranean coast, a perennial and stable population lives in the Thau lagoon (Charmantier 1974), the largest $\left(75 \mathrm{~km}^{2}\right)$ of the numerous lagoons along the Gulf of Lion, with salinity conditions ranging from 22 to $40 \%$.

The life cycle of $S$. serratum lasts 2 yr (Charmantier 1974, 1978). Spheroms hatch from the brood pouch (Fig. 1A, right) in spring and summer. After several molts as juveniles, they undergo sexual differentiation. The females (Fig. 1A, center) then alternately molt and reproduce at least twice before their death. For the males (Fig. 1A, left), the puberty molt is the final one. Afterwards they are sexually mature and called 'pubescent'; they later enter a period of physiological senescence ('senescent' males) preceding their death at the end of the summer (Charmantier 1974, 1978). During molting, the cuticle is shed along with the associated epibionts and a new prokaryotefree cuticle becomes available for further bacterial colonization. Bacteria were first observed on the pleopods of spheroms, particularly in the senescent males (Cazaméa-Catalan 2008), but the epibiotic community was not investigated in that study. The pleopods (abdominal appendages, Fig. 1B) are involved in respiration, osmoregulation and swimming. There are 5 pairs of pleopods (Fig. 1C), each with a leaf-shaped endo- and exopodite, that beat constantly to create a ventilation current. Moreover, very few studies have investigated the relationship between the development of an epibiotic community and the molting stage of the crustacean host (Charmantier \& Manier 1981, Corbari et al. 2008). For S. serratum, it was shown that the infestation rate of their proctodeum by a commensal fungus (Palavascia sphaeromae) is dependent on the stages of the cyclic molts, with a maximum level of infestation for senescent individuals that do no molt anymore (Charmantier \& Manier 1981).

The purpose of our study was (1) to investigate the epibiotic bacterial community of adult senescent males of Sphaeroma serratum, which ceased from molting. Our aim was to describe the spatial distribution of the microorganisms that developed on the pleopods of $S$. serratum. (2) We characterised the different bacterial morphotypes by electron microscopy and identified the phylogenetic affiliation using 16SRNA-specific probes by fluorescence in situ hybridization (FISH). (3) We investigated the possible relationship between molt status and the epibiotic bacterial community of spheroms at different stages of the life cycle (pubescent and senescent males, and females), which is not fully investigated in the literature.

\section{MATERIALS AND METHODS}

\section{Sphaeroma collection}

Specimens of Sphaeroma serratum were collected in the Thau lagoon, on the rocky beach of Balaruc les Bains. S. serratum live under stones where they hold tight onto the surface. The stones lie scattered in the lagoon in 10 to $80 \mathrm{~cm}$ depth, and in contact with 

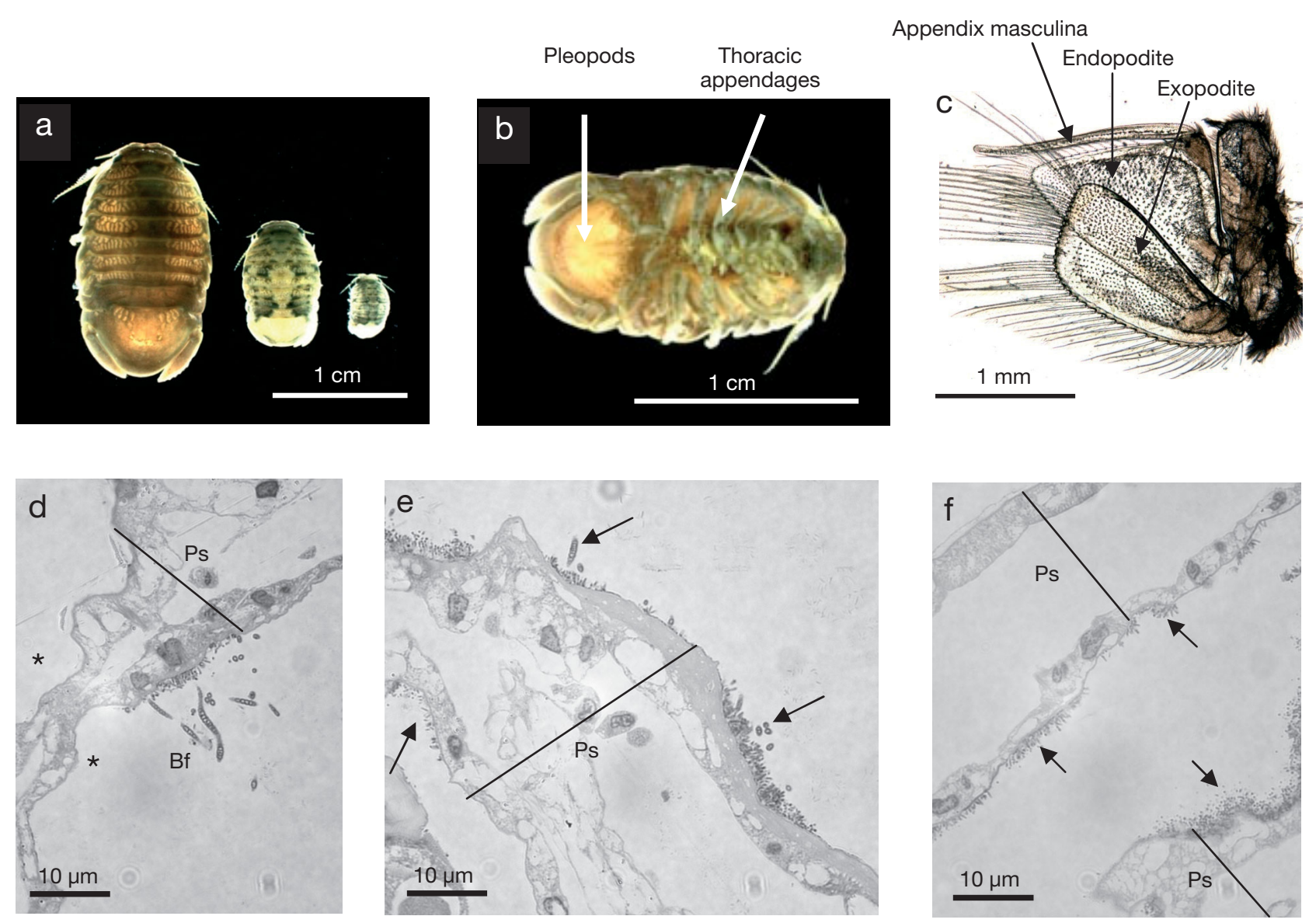

Fig. 1. Sphaeroma serratum. (a) Dorsal view of a pubescent male, female and juvenile (left to right). (b) Ventral view of an adult, showing pleopods in the posterior part of the abdomen. (c) Magnification of a pleopod, showing the leaf-shaped exopodite and endopodite. In mature males, a distinctive 'appendix masculina' is present on the second pair of pleopods. (d-f) Semi-thin sections of pleopods (Ps) stained with toluidine blue. (d) *: cuticle zones devoid of bacteria, along with sections of bacterial filaments (Bf). (e,f) Arrows: zones of cuticle covered by bacteria, either layered or erected on the cuticle

reduced sediments. Individuals were collected in July 2008 and were sorted under a dissecting microscope. Mature males present a distinctive 'appendix masculina' (Fig. 1C) on the second pair of pleopods and 2 penises on the ventral face. The degree of wear at the tip of the walking legs, more pronounced in the senescent males because they lack molting, makes it possible to distinguish between young mature (pubescent $=\mathrm{P})$ and oldest senescent $(=\mathrm{S})$ males. Approximately 50 individuals of each category were sorted for the different tests. Adult females (F individuals) lack a penis and appendix masculina.

\section{Fluorescence in situ hybridization}

Specimens were fixed in $2 \%$ paraformaldehyde (Merck) in seawater for $3 \mathrm{~h}$ and washed 3 times in sterile seawater before dehydration in an ethanol (Fluka) series (30, 50, 70, 95 and 100\%, 5 min each). Samples were stored at $-20^{\circ} \mathrm{C}$ before use. Whole pleopods were collected from the specimen under a binocular and progressively rehydrated with 95,80 and $70 \%$ ethanol (10 min each) consecutively. They were soaked in $\mathrm{HCl}\left(\mathrm{Sigma}_{\text {; }} 0.2 \mathrm{M}\right.$ ) and treated with proteinase $\mathrm{K}$ (Fermentas; $0.5 \mu \mathrm{g} \mathrm{ml}^{-1}$ in $20 \mathrm{mM}$ Tris buffer [Euromedex], $37^{\circ} \mathrm{C}$ for $5 \mathrm{~min}$ ). Oligonucleotide universal probes (EUB 338 and ARCH 915) were used for Bacteria and Archaea groups as well as more specific probes in order to screen for the main phylogenetic groups (i.e. $\alpha-, \beta-, \gamma$ - and $\delta$-Proteobacteria, the Bacteroidetes and the Planctomycetales) (Table 1). A negative control (Non EUB338 probe) was included in all FISH experiments. All the probes were labelled with cyanine 3 and were provided by Biomers Incorporation. 
Table 1. Oligonucleotides probes used and the rRNA position based on Escherichia coli numbering (Amann \& Fuchs 2008)

\begin{tabular}{|c|c|c|c|}
\hline Probe name & Target group & Probe sequence $\left(5^{\prime}-3^{\prime}\right)$ & rRNA position \\
\hline EUB338 & Bacteria & GCT GCC TCC CGT AGG AGT & $16 \mathrm{~S}(338-355)$ \\
\hline NON338 & Negative control & ACT CCT ACG GGA GGC AGC & 16S (338-355) \\
\hline ALF968 & $\begin{array}{l}\alpha \text {-Proteobacteria } \\
\quad \text { except Rickettsiales }\end{array}$ & GGT AAG GTT CTG CGC GTT & 16S (968-985) \\
\hline BET42a & $\beta$-Proteobacteria & GCC TTC CCA CTT CGT TT & 23S (1027-1043) \\
\hline GAM42a & $\gamma$-Proteobacteria & GCC TTC CCA CAT CGT TT & $23 \mathrm{~S}(1027-1043)$ \\
\hline DELTA 495a & $\delta$-Proteobacteria & AGT TAG CCG GTG CTT CCT & $16 \mathrm{~S}(1027-1043)$ \\
\hline CF319a & $\begin{array}{l}\text { Bacteroidetes } \\
\quad \text { (Cytophaga-Flavobacterium cluster) }\end{array}$ & TGG TCC GTG TCT CAG TAC & $16 \mathrm{~S}(319-336)$ \\
\hline PLA886 & Planctomycetales & GCC TTG CGA CCA TAC TCC C & 16S (886-904) \\
\hline ARCH915 & Archaea & GTG CTC CCC CGC CAA TTC CT & 16S (915-935) \\
\hline
\end{tabular}

Hybridization on whole pleopods was performed in the dark with probes at a final concentration of $5 \mathrm{ng}$ $\mathrm{ul}^{-1}$ in hybridization buffer according to the protocol described in Dubilier et al. (1995). After bacterial cell membranes were permeabilized using $\mathrm{HCl}$ (0.2 M, room temperature), Tris- $\mathrm{HCl}$ (Euromedex; $20 \mathrm{mM}$ $\mathrm{pH} 8$, room temperature) and proteinase $\mathrm{K}$ (Fermentas; $0.5 \mu \mathrm{g} \mathrm{ml} \mathrm{g}^{-1}$ in $20 \mathrm{mM}$ Tris- $\mathrm{HCl}$ buffer, $37^{\circ} \mathrm{C}$ ), hybridizations were performed using $20 \%$ formamide (Euromedex) at $46^{\circ} \mathrm{C}$ for $3 \mathrm{~h}$. Pleopods were then rinsed in washing buffer at $48^{\circ} \mathrm{C}$ for $15 \mathrm{~min}$ in the dark to remove unbound probes and were then washed in deionised water (Pernthaler et al. 2001, 2002). They were counter-stained for $10 \mathrm{~min}$ with DAPI (4 ,6 -diamidino-2-phenylindole; Sigma, final concentration: $2.5 \mu \mathrm{g} \mathrm{ml}^{-1}$ ) and rinsed in deionised water. Pleopods were mounted in mounting media (Prolong, Invitrogen) and observed with an Epi8Oi Nikon fluorescent microscope.

Confocal images were acquired on a Leica SPE confocal laser scanning system connected to a Leica DM 2500 upright microscope. Lasers were used at $\lambda_{\text {ex }}$ $532 \mathrm{~nm}$ for pleopods labelled with cyanine $3\left(\lambda_{\mathrm{em}}\right.$ 550-600 nm) and at $\lambda_{\text {ex }} 405 \mathrm{~nm}$ for DAPI $\left(\lambda_{\mathrm{em}} 420-\right.$ $480 \mathrm{~nm})$. A 40× ACS APO 1.15 oil Leica objective was used. Images were collected sequentially to avoid cross-contamination between fluorochromes and scanned at a resolution of $1024 \times 1024$ pixel resolution. Series of optical sections were collected.

\section{Scanning electron microscopy (SEM)}

For SEM, specimens were fixed in $4 \%$ formaldehyde (Merck) in filtered $(0.2 \mu \mathrm{m})$ seawater. Pleopods were carefully dissected, dehydrated in graded acetone (Carlo Erba; 30, 50, 70, 95 and 100\%, 5 min each), and critical-point dried using $\mathrm{CO}_{2}$ as transi- tional fluid in a Polaron Critical Point Drier. Then samples were sputter-coated with gold (Sputter Coater SC500, Biorad) and examined in a Hitachi S$2500 \mathrm{SEM}$ at an accelerating tension of $20 \mathrm{kV}$.

\section{Light microscopy (LM) and transmission electron microscopy (TEM)}

For LM, the samples were fixed in Bouin's fixative for $24 \mathrm{~h}$, washed and dehydrated in a series of graded ethanol (Carlo Erba) and embedded in paraplast (Carlo Erba). Serial sections $5 \mu \mathrm{m}$ thick were stained with Masson's trichrome (Martoja \& Martoja 1967).

TEM was performed on samples fixed in $2.5 \%$ glutaraldehyde (Sigma) in seawater for $24 \mathrm{~h}$ at room temperature. After dehydration, samples were embedded in Spurr's resin (Agar Scientific). Semi-thin $(0.5 \mu \mathrm{m})$ sections were obtained from the resin blocks using an ultramicrotome Ultracut E (Leica) and stained using Toluidine Blue (Carlo Erba) in 1\% borax buffer for LM observations. Ultra-thin section were cut on a Reichert OMU3 ultra-microtome, contrasted with $2 \%$ uranyl acetate (Carlo Erba) and lead citrate (Carlo Erba) and observed on a Jeol 1200 EX2 TEM at $70 \mathrm{kV}$.

\section{Denaturing gradient gel electrophoresis (DGGE)}

The diversity of the epibiotic bacterial community of specimen belonging to $\mathrm{F}, \mathrm{P}$ and $\mathrm{S}$ groups was assessed by DGGE.

The bacterial DNA was extracted from specimens stored in formaldehyde (Sigma; final concentration $4 \%)$ prepared with filtered sea water $(0.2 \mu \mathrm{m})$. Individual pleopods were grinded and homogenized in $1 \mathrm{ml}$ of $0.2 \mu \mathrm{m}$ filtered seawater. Samples were cen- 
trifuged for $5 \mathrm{~min}\left(4^{\circ} \mathrm{C}, 9600 \times g\right)$, supernatant was discarded and total DNA was extracted from the pellet following the modified protocol of Boström et al. (2004). DNA was extracted with $500 \mu \mathrm{l}$ of lysis buffer containing lysozyme (Euromedex; $30 \mathrm{~min}$, $37^{\circ} \mathrm{C}_{i} 1 \mathrm{mg} \mathrm{ml}^{-1}$ ), followed by incubation with proteinase K (Fermentas; $100 \mu \mathrm{g} \mathrm{ml}^{-1}$ ) and SDS (Sigma; $1 \%$ ) for $18 \mathrm{~h}$ at $55^{\circ} \mathrm{C}$. The lysate was recovered from the filter, which was rinsed with $500 \mu \mathrm{l}$ of TE buffer (10 mM Tris-HCl pH 7.5 [Euromedex], 1 mM EDTA (Fluka). The pooled lysates were then precipitated in $0.6 \mathrm{v} / \mathrm{v}$ of isopropanol (Fluka; $1 \mathrm{~h}$ at $-20^{\circ} \mathrm{C}$ ), centrifuged (20 min, $16100 \times g$ ), washed in $500 \mu \mathrm{l}$ of $70 \%$ ethanol (Fluka), before a last centrifugation (20 min, $16100 \times g$ ). The pellet was then dried in a speed vacuum for $10 \mathrm{~min}$ before being dissolved in $100 \mu \mathrm{l}$ of TE buffer (Euromedex), and stored at $-20^{\circ} \mathrm{C}$ prior to PCR amplification. The quality of the DNA extract was checked on an agarose gel and quantified using a Nanodrop ${ }^{\circledR}$ spectrometer (Labtech).

The V3 region of 16S rRNA genes from bacterial communities was amplified by PCR using 2 primers, 338f-GC (Ovreås et al. 1997) and 518r (Muyzer et al. 1993). PCR was performed using PuRe Taq ${ }^{\circledR}$ ReadyTo-Go ${ }^{\circledR}$ PCR beads (GE Healthcare) in a Mastercycler ${ }^{\circledR}$ ep (Eppendorf). A touchdown PCR was performed following Schauer et al. (2000): initial denaturation at $94^{\circ} \mathrm{C}$ for $5 \mathrm{~min}$; 10 touchdown cycles of denaturation (at $94^{\circ} \mathrm{C}$ for $1 \mathrm{~min}$ ), annealing (at $65 / 55^{\circ} \mathrm{C}$ for $1 \mathrm{~min}$, decreasing $1^{\circ} \mathrm{C}$ each cycle) and extension (at $72^{\circ} \mathrm{C}$ for $3 \mathrm{~min}$ ); 20 standard cycles of denaturation (at $94^{\circ} \mathrm{C}$ for $1 \mathrm{~min}$ ), annealing (at $55^{\circ} \mathrm{C}$ for $1 \mathrm{~min}$ ) and extension (at $72^{\circ} \mathrm{C}$ for $3 \mathrm{~min}$ ); and a final extension at $72^{\circ} \mathrm{C}$ for $5 \mathrm{~min}$.

PCR products were verified and quantified on an agarose gel. DGGE was performed with the INGENYphorU system (Ingeny). PCR products mixed with $7 \mu$ of loading buffer (Jena Bioscience) were loaded onto $6 \%(\mathrm{w} / \mathrm{v})$ polyacrylamide gels made with a denaturing gradient ranging from 45 to $60 \%$ (100\% denaturant contains $7 \mathrm{M}$ urea (Euromedex) and $40 \%$ deionized formamide (Euromedex). The electrophoresis was performed in 1× TAE buffer (Euromedex; $40 \mathrm{mM}$ Tris $\mathrm{pH} 7.4,20 \mathrm{mM}$ sodium acetate, $1 \mathrm{mM}$ EDTA) at $60^{\circ} \mathrm{C}$ at a constant voltage of $80 \mathrm{~V}$ for $18 \mathrm{~h}$. The gels were then stained for 10 min with $3 \mu$ of $10000 x$ SYBR ${ }^{\circledR}$ Green I (Molecular Probes) diluted in $30 \mathrm{ml} 1 \times$ TAE and visualized on gel doc system XR (Biorad) UV transilluminator, photographed with Quantity One software (Biorad). DGGE band patterns were analyzed with the software GELCompar II (Applied Maths) and transformed in a binary presence-absence matrix of all detected bands for each individual.
For statistical analysis, Jaccard distance was calculated from the presence-absence matrix, and used to produce a clustering tree with unweighted pairgroup average method (UPGMA). We investigated the differences in the number of DGGE band positions in the epibionts' fingerprint of 3 groups $(\mathrm{F}, \mathrm{P}$ and S) by 1-way ANOVA and Tukey's post-hoc test.

\section{RESULTS}

\section{Morphology of bacterial epibionts}

At least 5 distinct bacterial morphotypes were observed on the cuticle surface of appendages in all the male specimens examined. Morphotype 1 consisted of small rod-shaped bacteria (Fig. 2c), which were the most frequently occurring bacteria. Morphotype 2 consisted of long and thin rod-shaped bacteria (Fig. 2d). In addition, at least 3 different morphotypes $(3,4$ and 5$)$ occurred as bacterial filaments (Fig. 3b,d,e). Morphotype 1 varied in length from 1 to $2 \mu \mathrm{m}$, with a diameter of $\sim 0.5 \mu \mathrm{m}$ (Figs. $2 \mathrm{c} \& 3 \mathrm{a}$ ). The size of morphotype 2 varied from 3.5 to $6 \mu \mathrm{m}$ in length and $0.4 \mu \mathrm{m}$ in width (Fig. 2d). Morphotypes 1 and 2 occurred as prostrate (Fig. 2c,d) or erect bacteria (Fig. 2b). Both morphotypes (1 and 2) were also irregularly mixed in some areas (Figs. 2a \& 4b). Moreover, different morphotypes of filamentous bacteria were described (up to $200 \mu \mathrm{m}$ length), which were much less frequently observed than rods. They occurred individually (Fig. 2f) or more often as rosettes (Fig. 2e). Morphotype 3 occurred as large unsheathed filaments (Fig. 3b); their constitutive cells were barrel-like, with cells 14 to $16 \mu \mathrm{m}$ in diameter and 12 to $13 \mu \mathrm{m}$ in length. Some of them had started the division process (Fig. 3c). Their cytoplasm appeared to be filled with electron-lucent inclusions, which could represent sulfur granules as previously described for various sulfur-oxidizing ecto- and endo-symbionts of marine invertebrates (Pflugfelder et al. 2005, Lechaire et al. 2008) or iron polyphosphate granules as described in Rimicaris' epibiotic community (Zbinden et al. 2008). Morphotype 4 consisted of individual cells associated with sheathed trichome (Fig. 3d). The diameter and length of the cells were 0.3 and $0.6 \mu \mathrm{m}$, respectively. This morphotype displayed a typical gram-negative envelope and no peculiar internal structures apart from a large nucleoid in the center of the cell. Morphotype 5 exhibited dimensions similar to those of morphotype 4 and was also enveloped in a sheath, but they mainly differed by their intra-cytoplasmic content. 

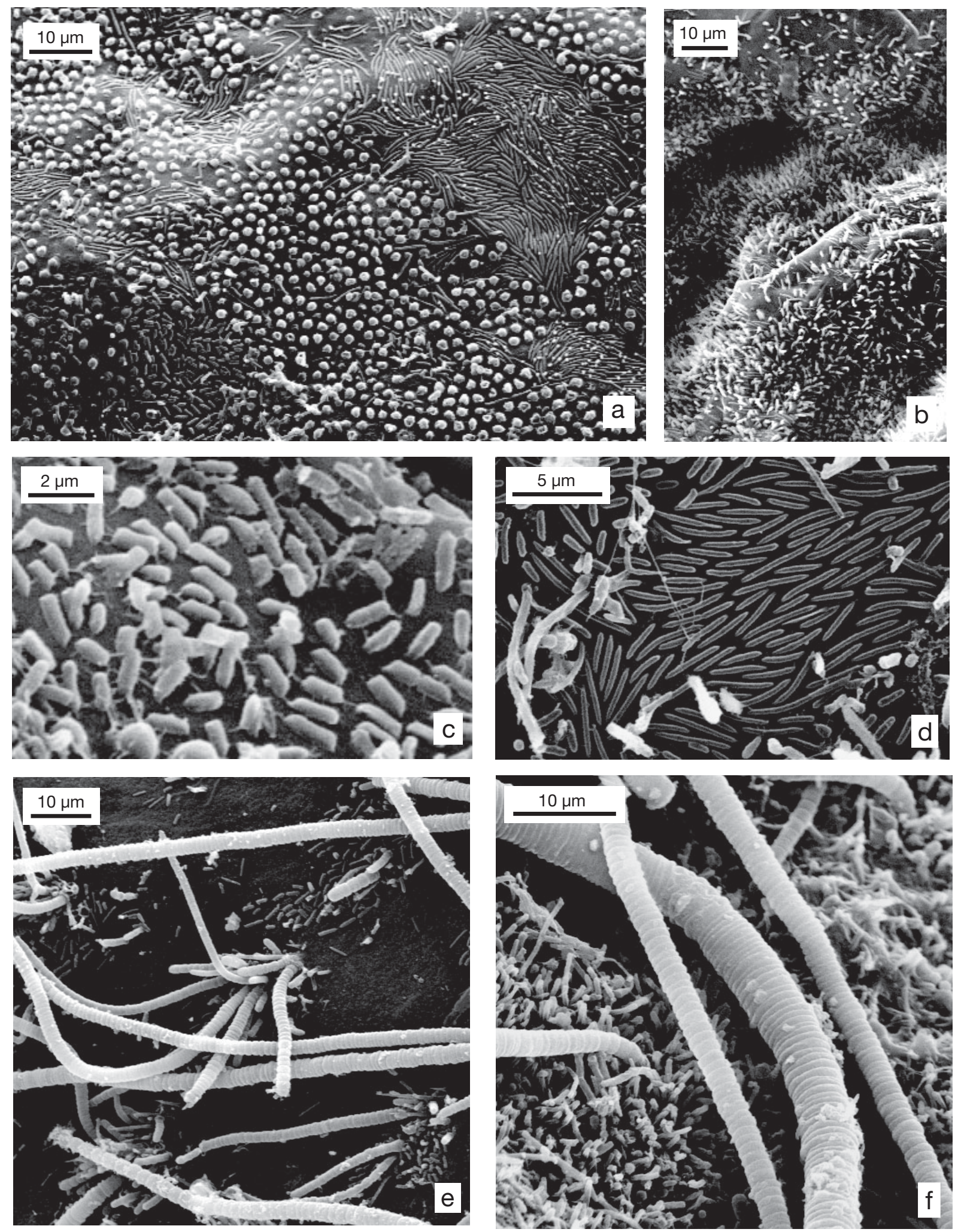

Fig. 2. Sphaeroma serratum. SEM micrographs of bacteria harboured on the cuticle of pleopods. (a) Two types of rod-shaped bacteria: small (morphotype 1) and long (morphotype 2), prostrated on the cuticle. (b) Rod-shaped bacteria erected on the cuticle. $(c, d)$ Details of rod-shaped morphotypes: monolayers of short rods, i.e. morphotype 1 (c), and long rods, i.e. morphotype 2 (d), prostrated on the cuticle. (e) Bacterial filaments forming a rosette-like structure. (f) Thin and thick bacterial filaments 

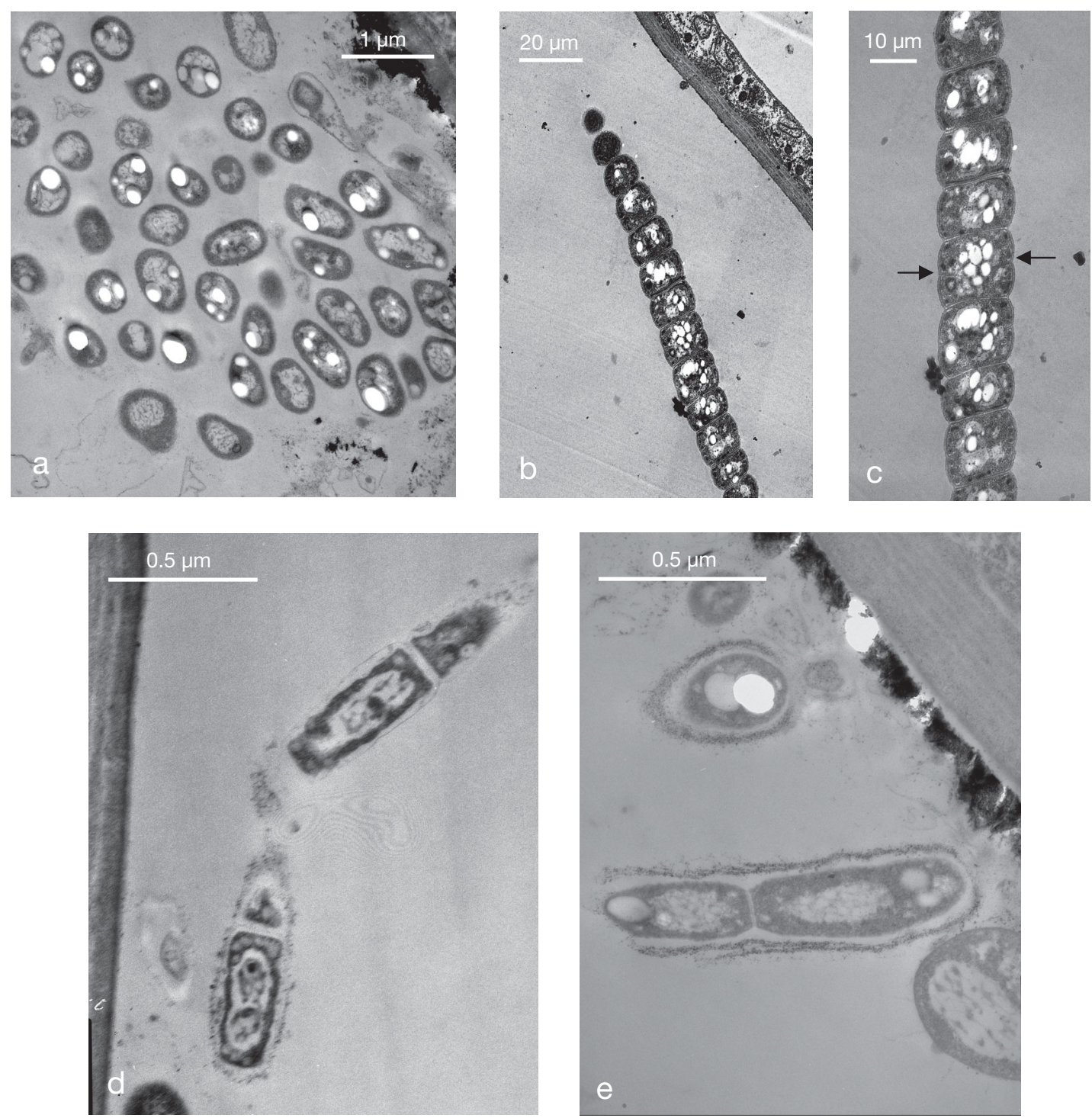

Fig. 3. Sphaeroma serratum. TEM micrographs of bacteria harboured on the cuticle of pleopods. (a) Transverse section of rodshaped bacteria with different types of electron-lucent inclusions. (b,c) Morphotype 3: bacterial filaments with electron-lucent inclusions and apparent cell division (arrows; c). (d) Morphotype 4: filamentous bacteria, with a sheath. (e) Morphotype 5: filamentous bacteria, with a sheath and refringent intracellular granules

Their cells contained at least 2 types of intracellular granules (Fig. 3e). The bacterial cytoplasm appeared homogenous, i.e. it contained a high number of ribosomes. Electron-lucent inclusions were obvious in these bacteria, in contrast to morphotype 4 .

\section{Spatial distribution patterns and phylogenetic affiliation of epibionts}

Rod-shaped bacteria (morphotypes 1 and 2) were distributed along the entire surface of the appendages whereas bacterial filaments (morphotypes 3, 4 and 5) were exclusively located at the periphery of the appendages (Fig. 4a,b). However, the density of rods can vary widely depending on the area examined and the time elapsed since the last molt. In the portion of the appendage covered by the next or previous one, the most frequent bacterial distribution consisted of a cluster organisation for rods (Figs. 2a \& $4 \mathrm{~b}$ ). But the periphery of those appendages (the noncovered portion) was sometimes entirely covered by rods, prostrate or erect, along with filamentous bacteria (Fig. 4a). The first stage of bacterial colonization of the cuticle leads to a micro-colony distribution of the bacteria (Fig. 4c,d), further leading to a biofilm 

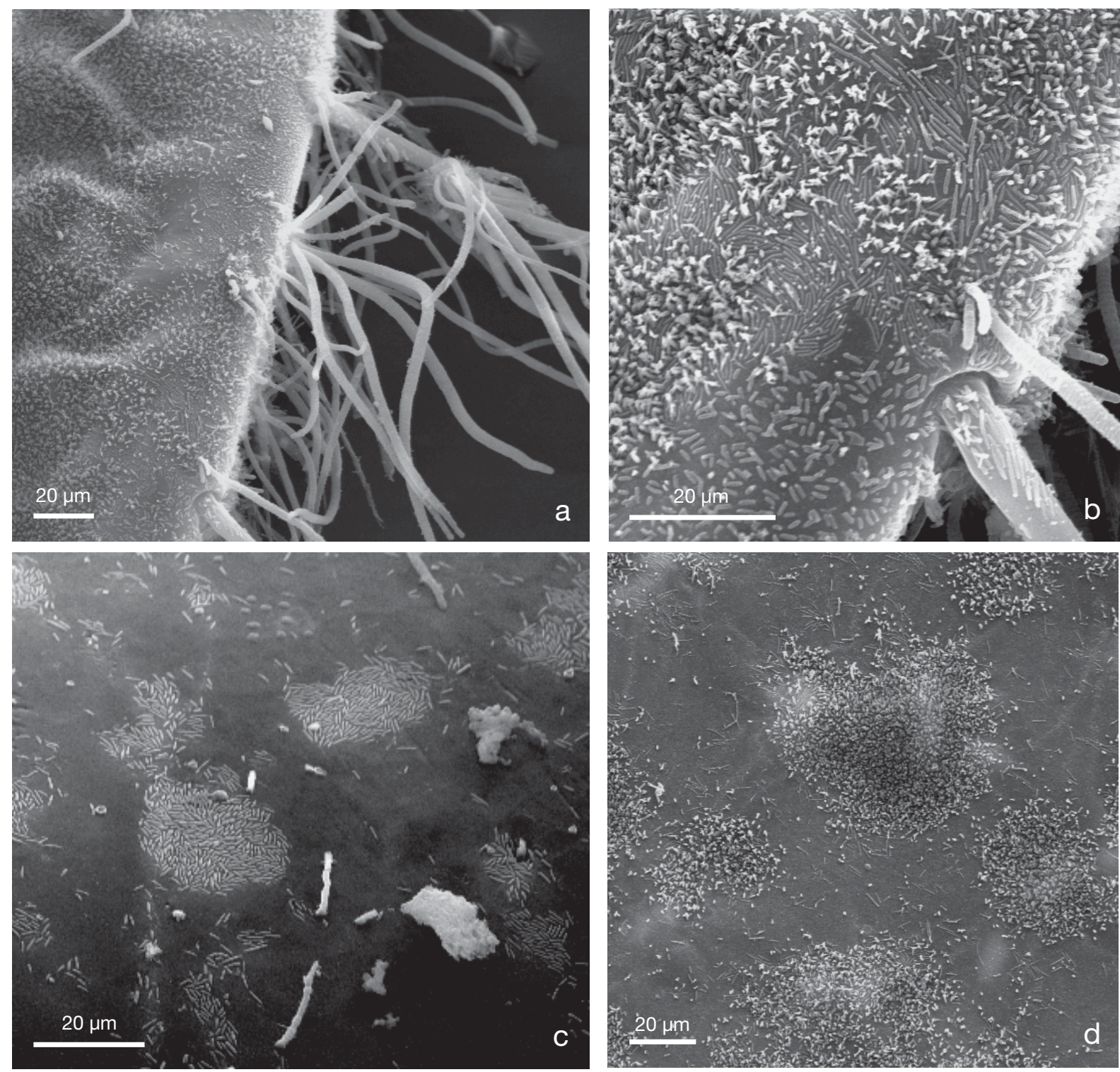

Fig. 4. Sphaeroma serratum. SEM micrographs of the bacteria harboured on the cuticle of pleopods. (a) Filamentous bacteria on the side of the pleopods. (b) Rod-shaped bacteria erected or prostrated on the cuticle, even on the setae of the pleopods. $(\mathrm{c}, \mathrm{d})$ Microcolonies of rod-shaped bacteria forming on the pleopods after renewal of the cuticle of during molting, with prostrated (c) or erected bacteria (d)

(Fig. 4b). The density of filamentous bacteria was highly variable, from isolated filaments to large areas covered by filamentous bacteria. The 5 bacterial morphotypes were also observed on the setae harboured by pleopods (data not shown).

Semi-thin sections of pleopods confirmed the irregular distribution of bacteria on the cuticle of appendages, where areas covered with bacteria and filamentous bacteria alternated with zones devoid of epibiotic bacteria (Fig. 1d). Moreover, semi-thin sections revealed that the colonization by rods existed as a bacterial biofilm characterised by a vari- able thickness (up to $7-8 \mu \mathrm{m}$ ). Theses biofilms also included some rare filaments (Fig. 1d). Bacterial biofilms occurred on both sides of the appendage or just on one side (Fig. 1e,f).

Based on hybridization with the universal probe EUB 338, both types of rods (morphotypes 1 and 2) and some bacterial filaments were confirmed to belong to Eubacteria (Fig. 5b). Moreover, some filamentous prokaryotic cells hybridized with the Archaea probe (Fig. 5h). Unfortunately, it was not possible to distinguish from FISH confocal images the different morphotypes of filamentous bacteria described by SEM 

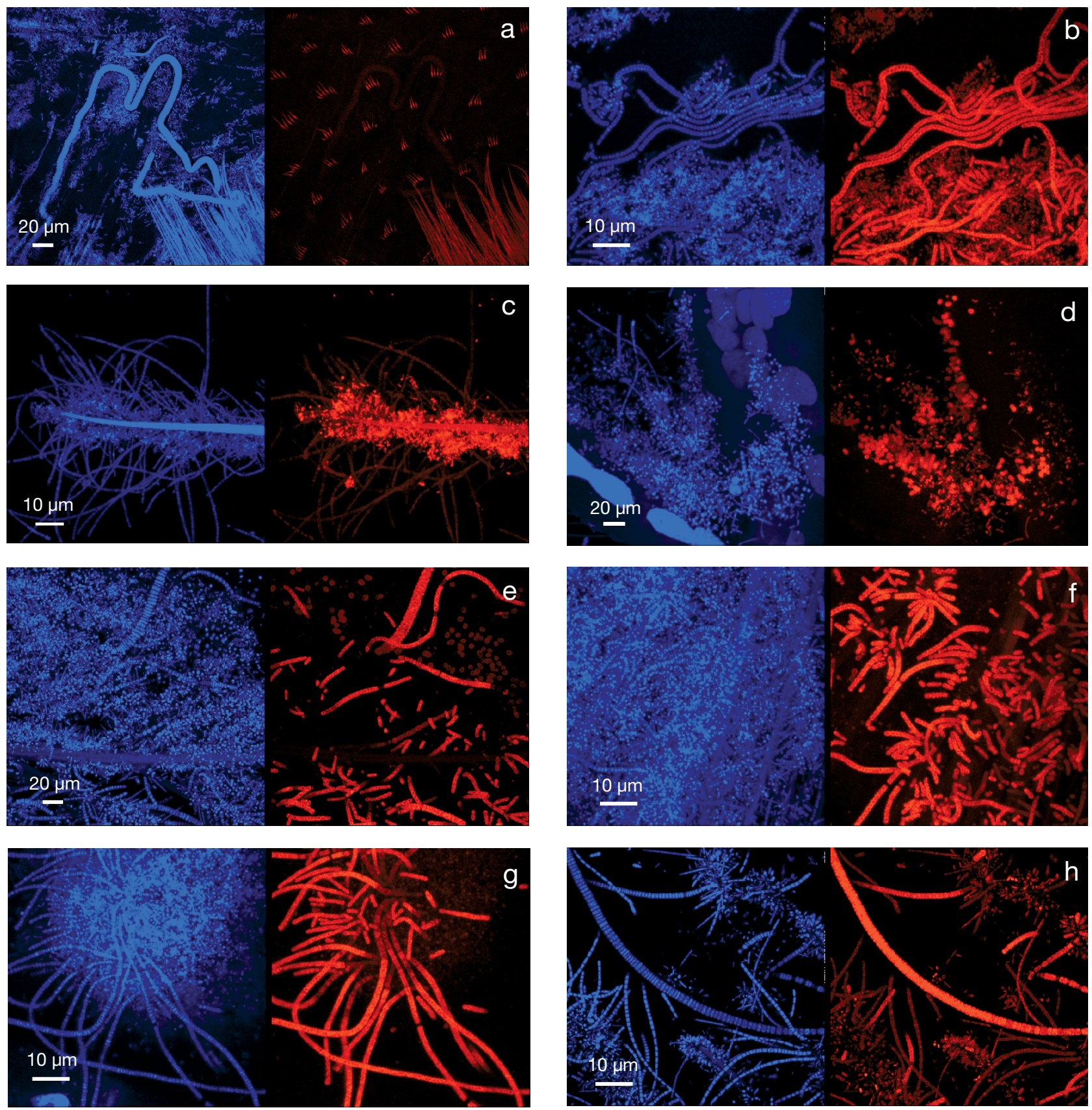

Fig. 5. Sphaeroma serratum. Fluorescent in situ hybridization (FISH), confocal laser scanning micrographs of the bacterial community that develops on the pleopods. Identical fields were visualized using filter sets specific for DAPI (4,6-diamidino-2phenylindole) (left) and for the specific probe labelled with CY3 (right). Autofluorescence of bacteria was tested (a). Hybridizations were performed with the Non-Eub probe for negative control (not shown), with the Eub probe as positive control (b) and with $\alpha$-Proteobacteria (c,d), $\beta$-Proteobacteria (e), $\gamma$-Proteobacteria (f), $\delta$-Proteobacteria (g) and Archaea (h)

observations. Among the 9 examined males, no signal was detected with the Non EUB338 negative control or with the Bacteroidetes- and Planctomycetales-specific probes. We also checked that bacteria were not autofluorescent (Fig. 5a). The most frequent morphotypes found on the Sphaeroma cuticle, i.e. morpho- types 1 and 2, were both identified as $\alpha$-Proteobacteria (Fig. 5c). The filamentous bacteria gave positive signal with $\alpha-, \beta-, \gamma$ - and $\delta$-Proteobacteria (Fig. 5d,g) and Archaea probes (Fig. 5h). The filamentous bacteria hybridized with the $\alpha$ probe were always composed of short filaments, with a few cells (Fig. 5d). 


\section{Bacterial community according to molt status}

One-way ANOVA revealed a significant different number of DGGE bands between groups ( $p<0.01$; Fig. 6a). A Tukey's post hoc test revealed that senescent (mean $\pm \mathrm{SD}=17.18 \pm 3.19)$ and pubescent $(17 \pm$ 3.36) groups were not statistically different ( $p>0.05)$ but that females $(12.66 \pm 2.90)$ exhibited a significant lower number of DGGE band positions than $\mathrm{P}$ or $\mathrm{S}$ group ( $\mathrm{p}<0.05)$.

Among the 35 examined specimens, we observed a total of 50 different DGGE band positions (Figs. 6b, 7, 8), $40 \%$ of them (i.e. 20 bands) were shared by the 3 groups ( $\mathrm{F}, \mathrm{P}$ and $\mathrm{S})$. These common DGGE bands are not evenly distributed among the 3 groups of epibiotic bacterial communities: 7 were mostly observed in $\mathrm{F}$ and $\mathrm{S}$ groups, 3 were mostly observed in the $\mathrm{P}$ group and 4 were mostly observed in the $\mathrm{S}$ group band patterns (data not shown). Pair-wise comparison of shared DGGE bands tended to differentiate F-P and S-P communities, and to cluster F and S communities by their disparate representation in band patterns. DGGE analysis tended to differentiate pubescent isopods from the 2 other groups (females and senescents).

The differences in the composition of the bacterial communities can be easily visualized on a clustering tree (Fig. 6c). The 12 pubescent males were clustered, indicating that their epibiotic bacterial community contains a distinct assemblage of DGGE bands when compared with $\mathrm{F}$ and $\mathrm{S}$ individuals. Although 3 and 2 individuals from the $\mathrm{S}$ and $\mathrm{F}$

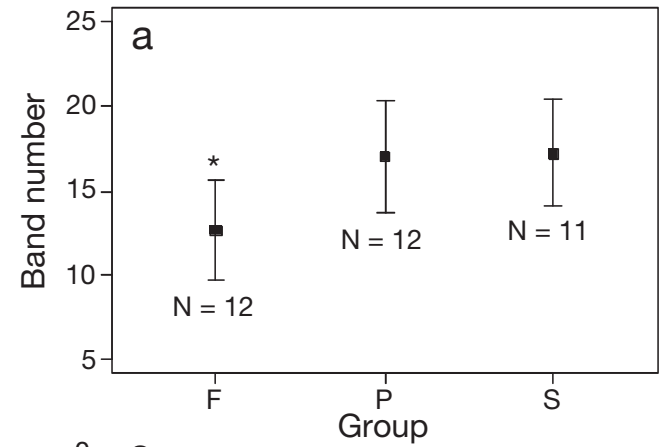

\begin{tabular}{|c|ccc|c|c|}
\hline b & F & P & S & FxPxS & Total \\
\hline F & 3 & & & & \\
P & 4 & 13 & & & \\
S & 2 & 7 & 1 & & \\
\hline FxPxS & & & & 20 & \\
\hline Total & \multicolumn{5}{|c}{50} \\
\hline
\end{tabular}

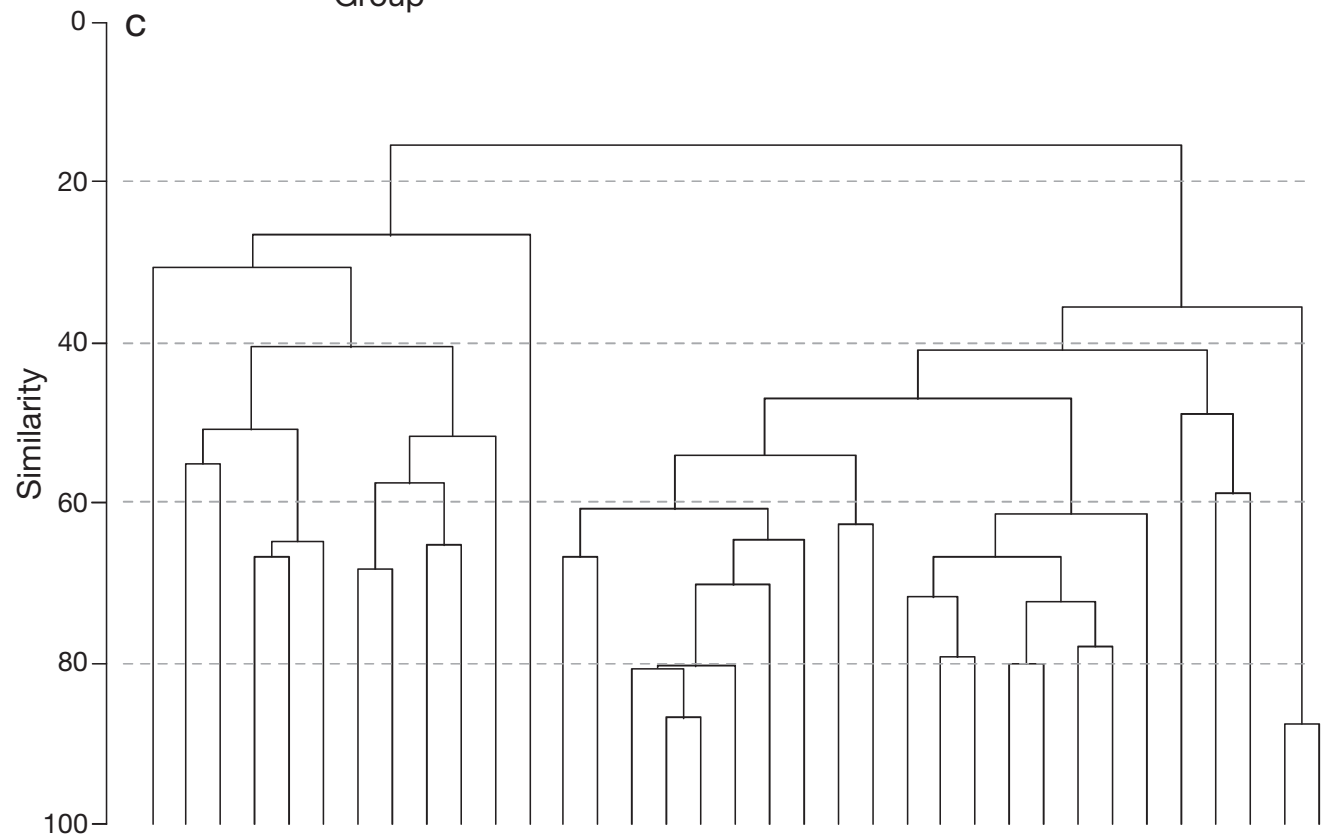

P P P P P P P P P F F F F F S F F S S S S S S S S F

Fig. 6. Sphaeroma serratum. (a) Number of bands per species (mean \pm SD) in the female (F), pubescent male (P) and senescent male (S) groups. N: number of individuals analyzed in each group. (b) Number of DGGE band positions shared between the F, $\mathrm{P}$ and $\mathrm{S}$ groups. (c) Dendrogram showing the relatedness of the microbial communities in 35 specimens. The dendrogram was constructed using the similarity matrix determined with the unweighted pair-group average method 
a

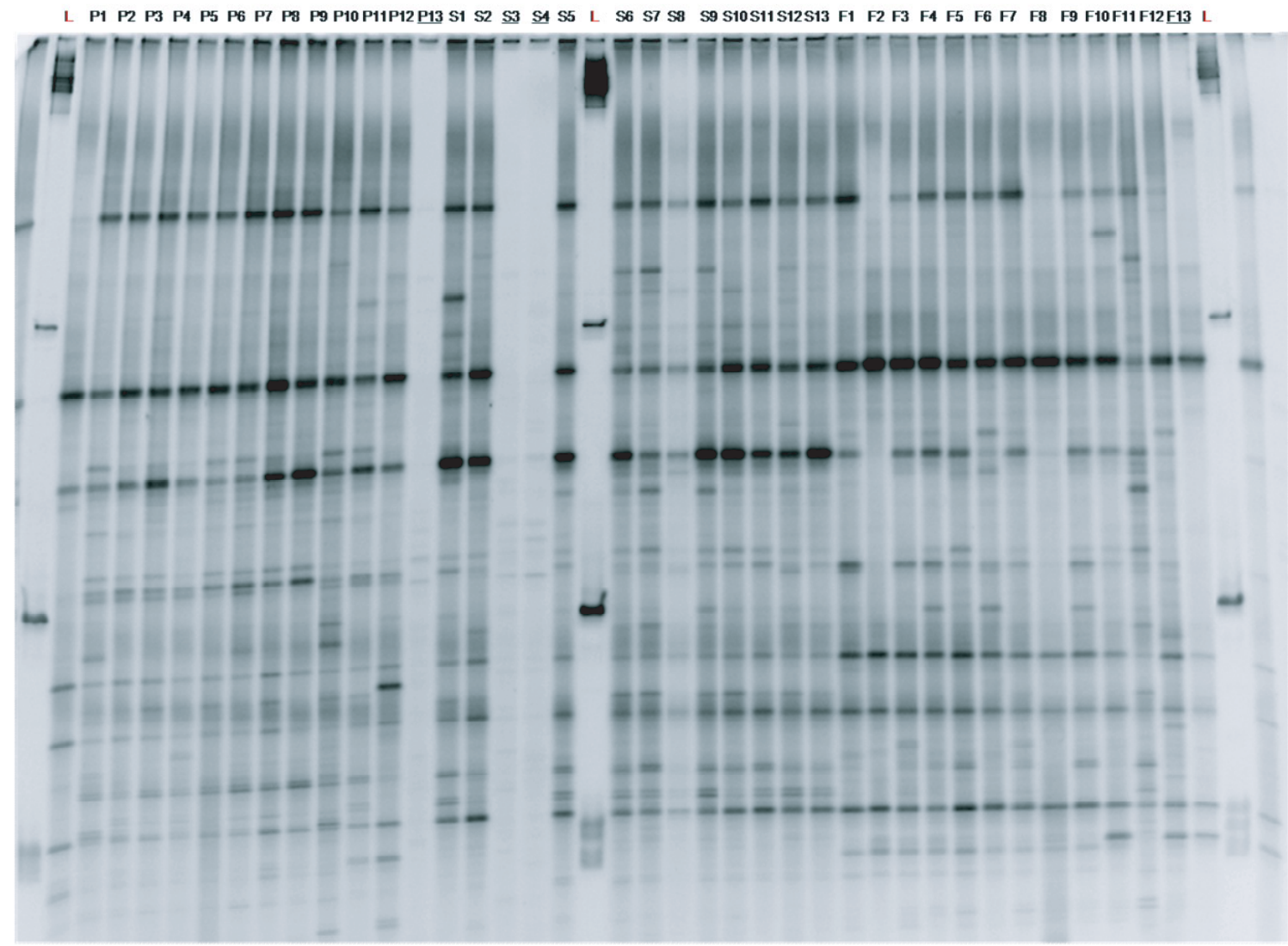

b

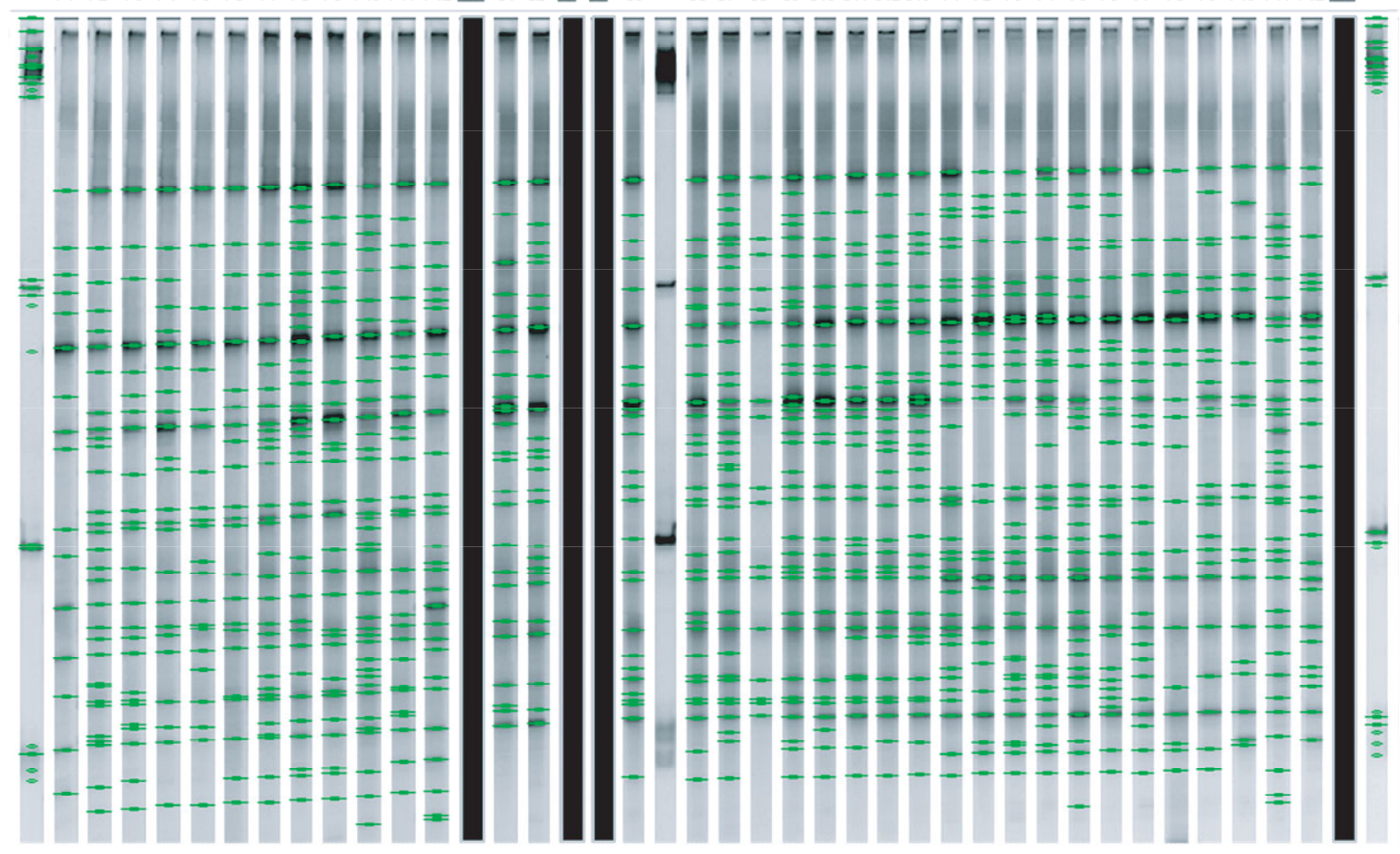

Fig. 7. (a) DGGE gel used for bacterial community analysis in 35 specimens. (b) Band assignment of DGGE profiles made with GelCompar software. Underlined specimens were not used for the analysis because their DGGE profile showed clear migration problems. F: females; P: pubescent males; S: senescent males 


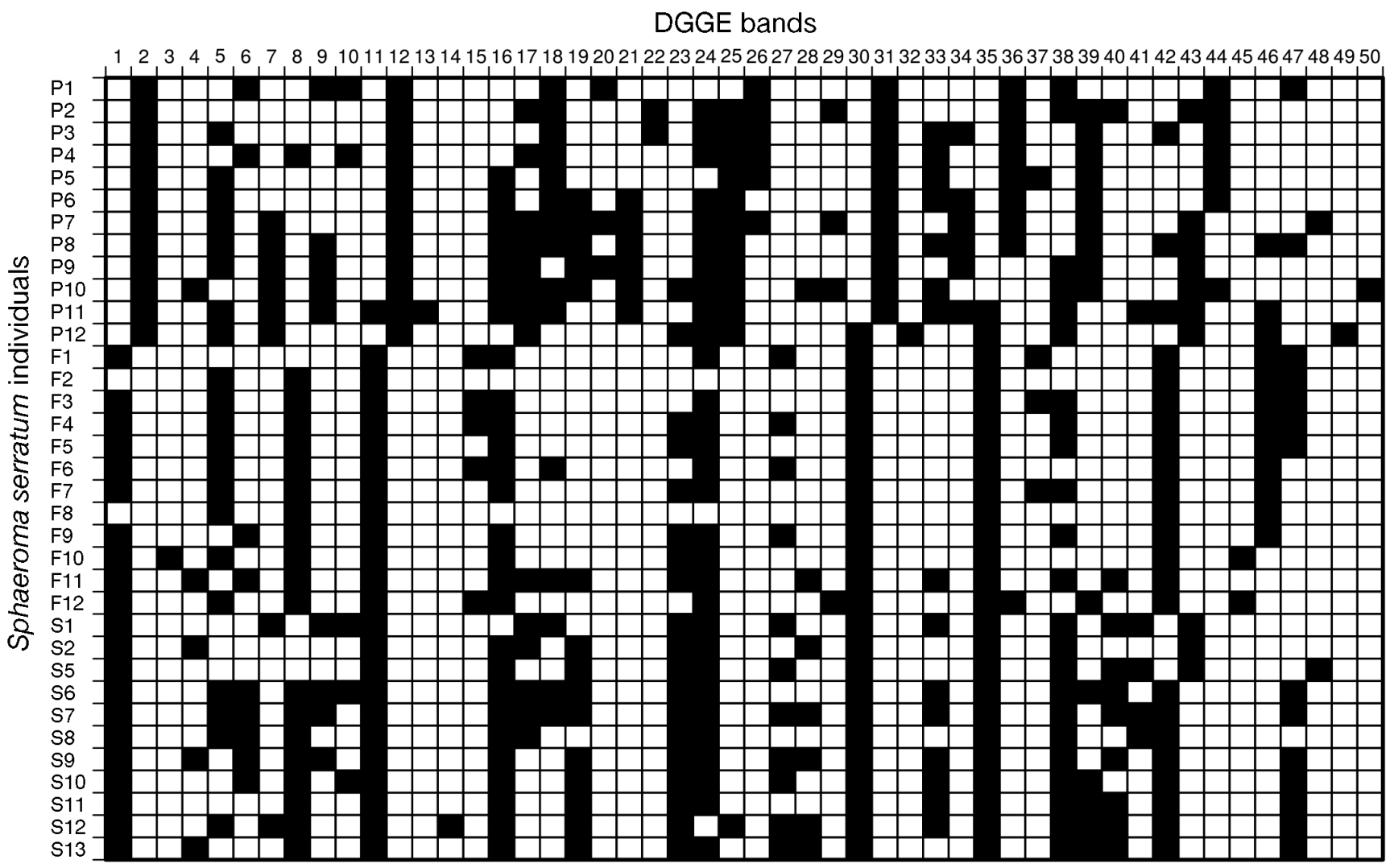

Fig. 8. Sphaeroma serratum. Presence-absence matrix of DGGE bands for bacterial communities analysis in 35 individuals. F: female; P: pubescent male; S: senescent male

groups, respectively, were separated from their own group, 2 highly similar clusters (> 50\%) corresponding to the $\mathrm{S}$ and $\mathrm{F}$ groups were observed, despite the existence of 2 outliers inside these clusters.

\section{DISCUSSION}

\section{Composition of the biofilm}

Morphological observations of the epibiotic community of Sphaeroma serratum revealed an epibiotic community composed of at least 3 morphotypes of filamentous bacteria and 2 morphotypes of rods. In the literature, several morphotypes of filamentous bacteria are frequently encountered on the same host species. Although morphology alone is of little use in identifying bacteria, some were related to sulfur-oxidizing bacteria such as Thiotrix (Gillan \& De Ridder 1997, Gillan \& Dubilier 2004, Gillan et al. 2004) or Leucothrix (Gillan et al. 2004, Petersen et al. 2010) according to morphology and molecular techniques. In the bacterial community hosted in the branchial chamber of Rimicaris (Crustaceae), 3 different mor- photypes were initially described $(2$ filamentous bacteria and one rod-shaped bacterium); they were affiliated with 3 different bacterial phylogenetic groups: the $\varepsilon$-Proteobacteria (Polz \& Cavanaugh 1995), the $\gamma$-Proteobacteria (Petersen et al. 2010) and the $\delta$-Proteobacteria (Hügler et al. 2011). For some marine nematodes, such as Eubostrichus dianae, the epibiotic bacterial community on the nematode cuticle can even be dominated by large filamentous sulfur-oxidizing bacteria that densely cover the entire surface of the nematode aside from morphologically distinct smaller bacteria (Polz et al. 1992, Himmel et al. 2009). Further investigations on this nematode revealed that the members of the bacterial community were, except for unidentified filamentous bacteria, cytophagas, sulphate-reducing bacteria and $\gamma$-Proteobacteria, which are commonly found in marine environments (Polz et al. 1999). FISH showed that the epibiotic community of $S$. serratum was mainly composed of Proteobacteria, with representatives of 4 deep branches, i.e. the $\alpha-, \beta-, \gamma$ - and $\delta$-Proteobacteria. FISH also revealed that morphotypes 1 and 2, both rod-shaped bacteria, were affiliated with the $\alpha$-Proteobacteria. In addition, although not abun- 
dant, some filaments were identified as members of Archaea. This high taxonomic diversity within the Proteobacteria coincides with a high degree of morphological diversity. Although the bacterioplankton community of the surrounding water was not investigated in the present study, Proteobacteria, Bacteroidetes and Actinobacteria are frequently reported from coastal waters (Fuhrman \& Ouverney 1998, Longnecker et al. 2005, Bouvier \& Del Giorgio 2007, Maurice et al. 2011). Surprisingly, neither Bacteroidetes nor Actinobacteria could be detected on the spherom cuticle. This fact suggests that (1) these groups are missing or weakly represented in the environment of the spherom or (2) they do not settle on and colonise the spherom cuticle. We compared our data of the biofilm of $S$. serratum with published data for another crustacean species, Rimicaris exoculata (Zbinden et al. 2008, Petersen et al. 2010, Hügler et al. 2011). This comparison revealed some similarities among the different biofilms despite the fact that they developed on different body parts. The extent and nature of the biofilm, both composed of rods and filamentous bacteria, and the diversity of the composition of the community in terms of phylogenetic groups were comparable. However, some differences were observed as $\alpha$ - and $\beta$-Proteobacteria occur in $S$. serratum biofilm and not in the biofilm of $R$. exoculata. For $S$. serratum, we did not study the presence of $\varepsilon$-Proteobacteria, which were found in the $R$. exoculata epibiont community. Indeed, $\varepsilon$-Proteobacteria are usually associated with invertebrates from hydrothermal vents (Alain et al. 2002, Goffredi et al. 2004, 2008, Suzuki et al. 2005) and from the mid-Atlantic ridge environment (López-García et al. 2002); thus it is unlikely that we would find any in the spherom environment.

\section{Relationship between molt and epibiotic bacterial diversity}

DGGE analysis revealed a high epibiotic microbial diversity, as 50 DGGE bands were detected by this molecular fingerprint technique on senescent individuals. The sensitivity of this technique allows another level of investigation of the diversity of the community of Sphaeroma serratum and could indicate that each phylogenetic group (5 in total) described by FISH probably comprises several bacterial species. This concurs with the fact that small and thin rods belong both to the same phylotype, i.e. the $\alpha$-Proteobacteria. Similarly, the 3 morphotypes of filamentous bacteria obviously belong to 5 phylogenetic groups $(\alpha-, \beta-, \gamma$ - and $\delta$-Proteobacteria and Archaea) and probably to a greater bacterial diversity. We are aware of the biases and limitations associated with the DGGE method of measuring bacterial diversity. DGGE can underestimate 'true diversity', as only dominant species in the bacterial community are detected (Kirk et al. 2004); moreover, different PCR products can also migrate to the same position. However, the number of DGGE bands observed in our study is high in comparison with other studies that have used this technique (Schauer et al. 2000, Díez et al. 2001), so we are confident that our description of microbial diversity is meaningful. The DGGE results clearly demonstrate that the diversity of the community varies according to the molt status. The lowest number of DGGE band positions occurs in the female group, where individuals go on molting during their whole life and get rid of the bacterial epibiont at the same time. Thus the more frequent molts in females result in a low level of diversity ( 12 DGGE bands per female individual) compared with males $(\sim 17)$, suggesting a clear effect of the molt on the diversity of the community. Based on these results, we could expect that pubescent males, which have molted shortly before sampling, would be less diversely colonized than senescent males, which molted for the last time several weeks or months before sampling. The results were not in agreement with this expectation. The mean number of bands per individual was equivalent in pubescent $(17 \pm$ 3.36) and senescent $(17.18 \pm 3.19)$ males. The DGGE band patterns of the epibionts of the pubescent males were separated from a clear cluster comprising both females and senescent males. We cannot explain these observations by our initial hypothesis that the composition of the biofilm develops through successional stages. Females molt frequently and are therefore expected to carry relatively young biofilms, as would be expected for pubescent males. In contrast, biofilms of pubescent males were several weeks to months old. It is thus surprising that DGGE band patterns of biofilms on females were more closely related to those of senescent males. Nevertheless, the time separating 2 molts was not taken into account in our study. Indeed, the major difference between pubescent and senescent males relates to the number of band specifically shared by both groups, i.e. 13 and 1 bands, respectively. This could originate from a multiple species colonization of the new free cuticle after the last molt, sustained by the microcolony structure of the biofilm observed by TEM. We sug- 
gest that on the freshly renewed cuticle, some of the bacteria species present in the environment or coming from horizontal transmission of the epibionts (Ghiorse 1984) can potentially settle and develop as microcolonies until competition occurs between species in the final structure of the biofilm. The 13 bacterial species apparently specific to the senescent group could indeed be bacteria that are able to settle and develop on a surface without competition but are unable to persist in a bacterial biofilm that is characterized by complex relationships between species and strong competition (Rao et al. 2005, Dang \& Lovell 2000). In agreement with our hypothesis, Polz et al. (1999) revealed that only a few bacterial populations that developed on the cuticle of Eubostrichus dianae (a marine nematode) were constitutive whereas the majority of populations were only transiently present. We corroborated this hypothesis as only 1 species was found specifically in the community of senescent males, whereas most of the species of the biofilm were shared by the other groups. Further studies should be addressed to identify a least some of the bacterial species present in the biofilm, either by band excision and sequencing or by cloning-sequencing. This could give more insights into the putative metabolic function of this biofilm and its potential role in the ecology of $S$. serratum.

\section{Putative role of the biofilm}

The biodiversity of the biofilm that develops specifically on the pleopods of Sphaeroma serratum raised questions about the interactions between the microorganisms and the host. A major question concerns the role of this biofilm or the disadvantage to the host. A specific localization of bacteria was described by Zbinden et al. (2004) in the hydrothermal shrimp Rimicaris exoculata. These authors demonstrated that iron deposits and the location of the epibiotic community inside the gill chamber of $R$. exoculata were spatially related. They hypothesized that the presence of iron-oxidising bacteria and iron deposits was promoted by the local microenvironment encountered in one part of the gill chamber, where $\mathrm{O}_{2}$ and $\mathrm{pH}$ were reduced following shrimp respiration. Moreover, a potential functional localization was recently suggested (Hügler et al. 2011), with a possibility of syntrophic exchange of sulfur compounds between sulfur-oxidizing and sulfur-reducing epibionts. In our study on $S$. serratum, the translucent granules hosted by filamentous bacteria could corre- spond either to iron granules or to sulfur granules, commonly found in epibiotic communities hosted by marine invertebrates living in sulfidic environments (Polz et al. 1992, 1994, Temara et al. 1993, Gillan \& Dubilier 2004, Zbinden et al. 2008, Petersen et al. 2010). The presence of iron- or sulfur-oxidizing bacteria in the epibiotic community of the spherom would be consistent with the location of these filamentous bacteria, specifically on the pleopods, and with the type of environment of $S$. serratum (reduced substrate under the stones). This suggests that the bacterial biofilm could benefit from the permanent supply of $\mathrm{O}_{2}$, created by the constant movement of the pleopods in order to sustain respiration for the host, together with a continuous supply of iron or sulfide from the reduced sediment. Observation from SEM reveals that the rich bacterial biofilm was strictly restricted to the pleopods; only scarcely were isolated bacteria observed on the cuticle of the body and on pereiopods. The hydrophobicity of the cuticle versus the hydrophilic structure of the bacterial wall was also evoked to explain why the cephalothoracic shield of the shrimp $R$. exoculata was devoid of bacteria (Zbinden et al. 2004). This was also observed for $S$. serratum. The cuticle of the pleopods of $S$. serratum could then present a modified structure, probably thinner with regard to the respiratory and osmoregulatory functions of pleopods. Epibiotic bacteria ingested by the host could represent a carbon source, as suggested for $R$. exoculata (Rieley et al. 1999), but in $S$. serratum we did not observe any scraped zones on the pleopods, nor any damaged biofilm, which makes this possibility unlikely. Moreover, S. serratum is known from stable isotope analysis as a grazer invertebrate that feeds on organic matter (Carlier et al. 2007). We suggest that the biofilm that develops on pleopods could be the result of passive colonization, without any selection by the host. This colonization starts on the free surface of the new cuticle with microcolonies and develops until a fully developed biofilm is formed, as described for $R$. exoculata (Corbari et al. 2008). However, the bacterial settlement and proliferation might be influenced by the microenvironment created by the constant movement of the pleopods and the environment where $S$. serratum lives, closely in contact with anoxic sediment given the black colour of the stone hosting the crustacean. Moreover, if the host selects bacteria, the community of individuals from different groups ( $\mathrm{F}, \mathrm{P}$ and $\mathrm{S}$ ) would be comparable in terms of diversity. When the host controls the settlement of bacteria through host defences, an extremely specific association between the host and its epibacteria occurs; this was demon- 
strated for the nematode Laxus sp. associated with a single bacterial species (Polz et al. 1994). Alternatively, the surface cuticle remains totally devoid of bacteria, which is a common feature for nematodes, as the vast majority of species are free of epigrowth (Polz et al. 1992). In S. serratum, as only 20 DGGE bands ( $40 \%$ of the total) were shared by the 35 analyzed spheroms, and because specific potential bacterial species arose in relation with the molt, we favour the hypothesis of a non-specific and stochastic colonization.

\section{CONCLUSIONS}

This is the first report on the epibiotic community colonizing Sphaeroma serratum. Beyond the diversity characterizing the bacterial community hosted by pleopods of $S$. serratum is the question of the ecological importance and functional role of this epibiotic community for the host. As this community was exclusively observed on the cuticle of pleopods, we propose that the settlement and development of this community benefit from the microenvironment of the spherom, rich in sulphide, and from microcurrents of $\mathrm{O}_{2}$-rich water generated by the beating of the pleopods for their respiratory and osmoregulatory functions. This could justify the presence of sulfur-oxidising bacteria occurring in the community as rods and filamentous bacteria. However, the modifications in the diversity of the community observed in this study in relation with the molt remains of great interest, as this topic is rarely investigated in the literature. Further studies are needed to identify the bacterial species that developed on the pleopods to give more insight into the metabolic diversity of the community to understand whether the spherom benefits from this association.

Acknowledgements. We thank Marc Troussellier and Marc Bouvy for stimulating this interdisciplinary study within the 'Ecologie des Systèmes Marins Côtiers' laboratory. We are also grateful to R. De Wit for critical reading of the manuscript and to G. Charmantier for grammar and punctuation checking.

\section{LITERATURE CITED}

Alain K, Olagnon M, Desbruyeres D, Page A and others (2002) Phylogenetic characterization of the bacterial assemblage associated with mucous secretions of the hydrothermal vent polychaete Paralvinella palmiformis. FEMS Microbiol Ecol 42:463-476

- Amann R, Fuchs BM (2008) Single-cell identification in microbial communities by improved fluorescence in situ hybridization techniques. Nat Rev Microbiol 6:339-348
Boström KH, Simu K, Hagstrom A, Riemann L (2004) Optimization of DNA extraction for quantitative marine bacterioplankton community analysis. Limnol Oceanogr Methods 2:365-373

> Bouvier T, Del Giorgio P (2007) Key role of selective viralinduced mortality in determining marine bacterial community composition. Environ Microbiol 9:287-297

Brigmon RL, De Ridder C (1998) Symbiotic relationship of Thiothrix spp. with an Echinoderm. Appl Environ Microbiol 64:3491-3495

Carlier A, Riera P, Amouroux JM, Bodiou JY and others (2007) A seasonal survey of the food web in the Lapalme Lagoon (northwestern Mediterranean) assessed by carbon and nitrogen stable isotope analysis. Estuar Coast Shelf Sci 73:299-315

Cazaméa-Catalan D (2008) Cycle biologique et adaptation de Sphaeroma serratum dans la lagune de Thau: impact du changement climatique. MSc dissertation, University of Montpellier II

Charmantier G (1974) Le cycle biologique de Sphaeroma serratum (Fabricius 1787) (Crustacea, Isopoda, Flabellifera) dans l'étang de Thau (Golfe du Lion). Vie Milieu 24:285-300

Charmantier G (1978) La mue de puberté et la sénescence chez les mâles de Sphaeroma serratum (Fabricius, 1787) (Crustacé, Isopoda, Flabellifera): écologie, métabolisme, endocrinologie. PhD dissertation, University of Montpellier II, France

Charmantier G, Manier JF (1981) Relation écologique entre Sphaeroma serratum (Fabricius 1787) (Crustacea, Isopoda, Flabellifera) et son commensal instestinal Palavascia sphaeromae. Vie Milieu 31:101-111

Corbari L, Zbinden M, Cambon-Bonavita MA, Gaill F, Compère $P(2008)$ Bacterial symbionts and mineral deposits in the branchial chamber of the hydrothermal vent shrimp Rimicaris exoculata: relationship to moult cycle. Aquat Biol 1:225-238

Daguerre de Hureaux N (1966) Etude du cycle biologique de Sphaeroma serratum au Maroc. Bull Soc Sci Nat Phys Maroc 46:19-52

Dang H, Lovell C (2000) Bacterial primary colonization and early succession on surfaces in marine waters as determined by amplified rRNA gene restriction analysis and sequence analysis of 16S rRNA genes. Appl Environ Microbiol 66:467-475

> Dattagupta S, Schaperdoth I, Montanari A, Mariani S, Kita N, Valley J, Macalady J (2009) A novel symbiosis between chemoautotrophic bacteria and a freshwater cave amphipod. ISME J 3:935-943

> Desbruyères $\mathrm{D}$, Chevaldonné $\mathrm{P}$, Alayse AM, Jollivet D and others (1998) Biology and ecology of the "Pompeii worm" (Alvinella pompejana Desbruyeres and Laubier), a normal dweller of an extreme deep-sea environment: a synthesis of current knowledge and recent developments. Deep-Sea Res II 45:383-422

> Díez B, Pedrós-Alío C, Marsh TL, Massana R (2001) Application of denaturing gradient gel electrophoresis (DGGE) to study the diversity of marine picoeukaryotic assemblages and comparison of DGGE with other molecular techniques. Appl Environ Microbiol 67:2942-2951

> Dubilier N, Giere O, Distel D, Cavanaugh C (1995) Characterization of chemoautotrophic bacterial symbionts in a gutless marine worm (Oligochaeta, Annelida) by phylogenetic 16S rRNA sequence analysis and in situ hybridization. Appl Environ Microbiol 61:2346-2350 
Dubilier N, Bergin C, Lott C (2008) Symbiotic diversity in marine animals: the art of harnessing chemosynthesis. Nat Rev Microbiol 6:725-740

El-Shanshoury AR, Mona MH, Shoukr FA, El-Bossery AM (1994) The enumeration and characterization of bacteria and fungi associated with marine wood-boring isopods, and the ability of these microorganisms to digest cellulose and wood. Mar Biol 119:321-326

Fuhrman JA, Ouverney CC (1998) Marine microbial diversity studied via $16 \mathrm{~S}$ rRNA sequences: cloning results from coastal waters and counting of native archaea with fluorescent single cell probes. Aquat Ecol 32:3-15

> Gebruk AV, Pimenov NV, Savichev AS (1993) Feeding specialization of bresiliid shrimps in the TAG site hydrothermal community. Mar Ecol Prog Ser 98:247-253

Ghiorse WC (1984) Biology of iron- and manganese-depositing bacteria. Annu Rev Microbiol 38:515-550

> Gillan DC, De Ridder C (1997) Morphology of a ferric ironencrusted biofilm forming on the shell of a burrowing bivalve (Mollusca). Aquat Microb Ecol 12:1-10

Gillan DC, Dubilier N (2004) Novel epibiotic Thiothrix bacterium on a marine Amphipod. Appl Environ Microbiol 70:3772-3775

Gillan DC, Speksnijder A, Zwart G, De Ridder C (1998) Genetic diversity of the biofilm covering Montacuta ferruginosa (Mollusca, Bivalvia) as evaluated by denaturing gradient gel electrophoresis analysis and cloning of PCRamplified gene fragments coding for 16r RNA. Appl Environ Microbiol 64:3464-3472

Gillan D, Ribesse J, De Ridder C (2004) The iron-encrusted community of Urothoe poseidonis (Crustacea, Amphipoda). J Sea Res 52:21-32

> Goffredi SK, Warén A, Orphan VJ, Van Dover CL, Vrijenhoek RC (2004) Novel forms of structural integration between microbes and a hydrothermal vent gastropod from the Indian ocean. Appl Environ Microbiol 70 : 3082-3090

> Goffredi SK, Jones WJ, Erhlich H, Springer A, Vrijenhoek RC (2008) Epibiotic bacteria associated with the recently discovered Yeti crab, Kiwa hirsuta. Environ Microbiol 10: 2623-2634

> Himmel D, Maurin LC, Gros O, Mansot JL (2009) Raman microspectrometry sulphur detection and characterization in the marine ectosymbiotic nematode Eubostrichus dianae (Desmodoridae, Stilbonematidae). Biol Cell 101: 43-54

Hügler M, Petersen J, Dubilier N, Imhoff J, Sievert S (2011) Pathways of carbon and energy metabolism of the epibiotic community associated with the deep-sea hydrothermal vent shrimp Rimicaris exoculata. PLoS ONE 6: e16018

Katz S, Cavanaugh CM, Bright M (2006) Symbiosis of epiand endocuticular bacteria with Helicoradomenia spp. (Mollusca, Aplacophora, Solenogastres) from deep-sea hydrothermal vents. Mar Ecol Prog Ser 320:89-99

> Kirk JL, Beaudette LA, Hart M, Moutoglis P, Khironomos JN, Lee H, Trevors JT (2004) Methods of studying soil microbial diversity. J Microbiol Methods 58:169-188

> Lackschewitz D, Reise K (1998) Macrofauna on flood delta shoals in the Wadden Sea with an underground association between the lugworm Arenicola marina and the amphipod Urothoe poseidonis. Helgol Meersunters 52: 147-158

> Lechaire JP, Frebourg G, Gaill F, Gros O (2008) In situ characterization of sulphur in gill-endosymbionts of the shal- low water lucinid Codakia orbicularis (Linné, 1758) by high-pressure cryofixation and EFTEM microanalysis. Mar Biol 154:693-700

- Longnecker K, Sherr E, Sherr B (2005) Activity and phylogenetic diversity of high and low nucleic acid content, and ETS-active, bacterial cells in an upwelling ecosystem. Appl Environ Microbiol 71:7737-7749

> López-García P, Gaill F, Moreira D (2002) Wide bacterial diversity associated with tubes of the vent worm Riftia pachyptila. Environ Microbiol 4:204-215

Martoja R, Martoja M (1967) Initiation aux techniques de l'histologie animale. Masson, Paris

> Maurice CF, Mouillot D, Bettarel Y, De Wit R, Sarmento H, Bouvier T (2011) Disentangling the relative influence of bacterioplankton phylogeny and metabolism on lysogeny in reservoirs and lagoons. ISME J 5:831-842

> Muyzer G, Dewaal EC, Uitterlinden AG (1993) Profiling of complex microbial-populations by denaturing gradient gel-electrophoresis analysis of polymerase chain reaction-amplified genes-coding for 16S ribosomal-RNA. Appl Environ Microbiol 59:695-700

> Ovreås L, Forney L, Daae FL, Torsvik V (1997) Distribution of bacterioplankton in meromictic Lake Saelenvannet, as determined by denaturing gradient gel electrophoresis of PCR-amplified gene fragments coding for 16S rRNA. Appl Environ Microbiol 63:3367-3373

Pernthaler J, Glöckner FO, Schönhuber W, Amann R (2001) Fluorescence in situ hybridization (FISH) with rRNA-targeted oligonucleotide probes. Methods Microbiol 30: 208-226

Pernthaler A, Pernthaler J, Amann R (2002) Fluorescence in situ hybridization and catalyzed reporter deposition for the identification of marine bacteria. Appl Environ Microbiol 68:3094-3101

Petersen JM, Ramette A, Lott C, Cambon-Bonita MA, Zbinden M, Dubilier N (2010) Dual symbiosis of the vent shrimp Rimicaris exoculata with filamentous gamma- and epsilon- Proteobacteria at four Mid-Atlantic Ridge hydrothermal vent fields. Environ Microbiol 12:2204-2218

> Pflugfelder B, Fisher CR, Bright M (2005) The color of the trophosome: elemental sulphur distribution in the endosymbionts of Riftia pachyptila (Vestimentifera; Siboglinidae). Mar Biol 146:895-901

Polz MF, Cavanaugh CM (1995) Dominance of one bacterial phylotype at a Mid-Atlantic Ridge hydrothermal vent site. Proc Natl Acad Sci USA 92:7232-7236

Polz MF, Felbeck H, Novak R, Nebelsick M, Ott A (1992) Chemoautotrophic, sulfur-oxidizing symbiotic bacteria on marine nematodes: morphological and biochemical characterization. Microb Ecol 24:313-329

> Polz MF, Distel D, Zarda B, Amann R, Felbeck H, Ott A, Cavanaugh C (1994) A highly specific association between ectosymbiotic, sulfur-oxidizing bacteria and a marine nematode and its phylogenetic relationship to endosymbionts and free-living bacteria. Appl Environ Microbiol 60:4461-4467

Polz MF, Harbison C, Cavanaugh CM (1999) Diversity and heterogeneity of epibiotic bacterial communities on the marine nematode Eubostrichus dianae. Appl Environ Microbiol 65:4271-4275

> Rao D, Webb J, Kjelleberg S (2005) Competitive interactions in mixed-species biofilms containing the marine bacterium Pseudoalteromonas tunicata. Appl Environ Microbiol 71:1729-1736

Rieley G, Van Dover CL, Hedrick DB, Eglinton G (1999) 
Trophic ecology of Rimicaris exoculata: a combined lipid abundance/stable isotope approach. Mar Biol 133: 495-499

Schauer M, Massana R, Pedros-Alio C (2000) Spatial differences in bacterioplankton composition along the Catalan coast (NW Mediterranean) assessed by molecular fingerprint. FEMS Microbiol Ecol 33:51-59

Segonzac M, Desaintlaurent M, Casanova B (1993) L'énigme du comportement trophique des crevettes Alvinicarididae des sites hydrothermaux de la dorsale médio atlantique. Cah Biol Mar 34:535-571

Suzuki Y, Sasaki T, Suzuki M, Nogi Y and others (2005) Novel chemoautotrophic endosymbiosis between a member of the epsilon-Proteobacteria and the hydrothermal vent gastropod Alviniconcha aff. Hessleri (Gastropoda: Provannidae) from the Indian Ocean. Appl Environ Microbiol 71:5440-5450

Tait E, Carman M, Sievert S (2007) Phylogenetic diversity of bacteria associated with ascidians in Eel Pond (Woods Hole, Massachusetts, USA). J Exp Mar Biol Ecol 342: 138-146

Editorial responsibility: Peter Steinberg,

Sydney, New South Wales, Australia
Temara A, De Ridder C, Kuenen J, Robertson L (1993) Sulfide-oxidizing bacteria in the burrowing echinoid, Echinocardium cordarum (Echinodermata). Mar Biol 115:179-185

Van Dover CL, Fry B, Grassle JF, Humphris S, Rona PA (1988) Feeding biology of the shrimp Rimicaris exoculata at hydrothermal vents on the Mid-Atlantic Ridge. Mar Biol 98:209-216

Williams AB, Rona PA (1986) Two new caridean shrimps (Bresiliidae) from a hydrothermal field on the MidAtlantic Ridge. J Crustac Biol 6:446-462

Zbinden M, Le Bris N, Gaill F, Compère P (2004) Distribution of bacteria and associated minerals in the gill chamber of the vent shrimp Rimicaris exoculata and related biogeochemical processes. Mar Ecol Prog Ser 284: $237-251$

> Zbinden M, Shilito B, Le Bris N, De Villardi de Montlaur C and others (2008) New insigths on the metabolic diversity among the epibiotic microbial community of the hydrothermal vent shrimp Rimicaris exoculata. J Exp Mar Biol Ecol 359:131-140

Submitted: July 25, 2011; Accepted: March 08, 2012 Proofs received from author(s): June 12, 2012 